\title{
SHIFT WORK AND CANCER: STATE OF SCIENCE AND PRACTICAL CONSEQUENCES*
}

\author{
Mei YONG and Michael NASTERLACK \\ Occupational Medicine \& Health Protection Department BASF SE, Ludwigshafen, Germany \\ Received in January 2012 \\ CrossChecked in January 2012 \\ Accepted in April 2012
}

\begin{abstract}
In 2007, an expert Working Group convened by the IARC Monographs Programme concluded that shift work that involves circadian disruption is probably carcinogenic to humans (Group 2A). We scrutinised the epidemiological basis for this conclusion, with a focus on, but not limited to, breast and prostate cancers. We further considered practical consequences for shift workers in our industry against the background of new findings.

We carried out a literature search including the epidemiological studies cited by IARC and newer available literature on shift work and cancer.

Since the IARC assessment, eleven new studies have emerged, ten of which have already been published, with inconclusive results. Heterogeneity of exposure metrics and study outcomes and emphasis on positive but non-significant results make it difficult to draw general conclusions. Also, several reviews and commentaries, which have been published meanwhile, came to equivocal results. Published evidence is widely seen as suggestive but inconclusive for an adverse association between night work and breast cancer, and limited and inconsistent for cancers at other sites and all cancers combined.

At this point in time it can not be ruled out that shift work including night work may increase the risk for some cancers in those who perform it. However, shift schedules can be organised in ways that minimise the associated health risks, and the risks may be further reduced through the implementation of structured and sustained health promotion programs specifically tailored to the needs of shift workers.
\end{abstract}

KEY WORDS: breast cancer, circadian disruption, night work, prostate cancer

Nearly $20 \%$ of the working population in Europe and North America works in shifts and because of the nature of the production processes involved - the chemical industry is particularly dependent on this type of work organisation. In 2007, an expert Working Group convened by the International Agency for the Research on Cancer (IARC) Monographs Programme concluded on the basis of "limited evidence in humans for the carcinogenicity of shift work that involves night work", and "sufficient evidence in experimental

\footnotetext{
* Partly presented at the $39^{\text {th }}$ International MEDICHEM Congress on Occupational and Environmental Health in the Production and Use of Chemical "Occupational Health in a Changing World", Heidelberg, Germany, 2 - 5 June 2011
}

animals for the carcinogenicity of light during the daily dark period (biological night)" that shift work that involves circadian disruption is probably carcinogenic to humans (Group 2A) (1). This ruling, which was only published as a short "policy watch" notice, was soon challenged by other scientists on the basis of a systematic review of the relevant literature (2). However, an in-depth discussion of the IARC assessment has only recently become possible due to the fact that the full monograph was only published three years after the first communication (3). In this article we will shortly summarise the epidemiological basis for the IARC assessment and address some 
inconsistencies, which in our opinion had been given too little weight by IARC. We will then summarise the new literature on this topic and finally, based on practical experience from a major chemical company in Germany, address the question of consequences for the shift work organisation in industry. For the purpose of this article, shift work is always considered as work involving night work.

\section{THE IARC ASSESSMENT}

The IARC ruling was mainly based on two types of study populations; first, the published cancer experience from nurse cohort members with and without shift work, and second, the respective findings in flight attendants and pilots. In the latter case, longhaul flights across time zones were taken as a proxy for shift work, because they were considered to cause "circadian disruption", a concept which IARC sees as instrumental for the development of cancer in so exposed persons. Noteworthy, on the 200 pages of the monograph the term "circadian disruption" occurs approximately 40 times, with no definition provided. For the purpose of the following discussion we may tentatively assume that it refers to desynchronisation of two or more of the more than hundred known physiological processes, which show circadian periodicity in humans. However, IARC leaves open the question of which ones may be of relevance, and to which degree such a disruption would have to occur to be of biological significance.

As a matter of fact, most of IARC's ruling is thus based on the reports of female breast cancer. In evaluating the evidence in humans, IARC offers a very straight-forward approach: six out of eight studies (excluding female flight attendants) included in the review have shown modestly elevated risks, and the incidence of breast cancer was also modestly increased in most cohorts of female flight attendants (1). The following Table 1 with the main results from the eight studies in "non-aircraft" populations shows that this simplified comparison may not represent the full picture.

Elevated breast cancer risks appear either after having worked in shifts for 30 years $(4,9)$, or after a cumulative exposure to shift work of only six months (8). They also appear after having worked in shifts for a little more than three years, but only in women aged 50 years or more (7). Thus, even in this small subset of studies there is considerable heterogeneity regarding dose metrics and dose-response relations.

IARC scrutinised nine studies on breast cancer in aircraft crew (12-20). Most risk estimates from these studies are in the range between 1 and 2, but only four out of the nine studies reach at least borderline statistical significance $(12,14,16,18)$. IARC acknowledges the fact that aircraft crew is exposed to other possible carcinogenic agents, most notably cosmic radiation. Indeed, most of the aircraft crew studies were originally targeted at the effects of cosmic radiation, estimating cumulative radiation doses as exposure of interest. IARC explicitly assumes that the number of flights across several time zones, which is used as a proxy of frequency of circadian rhythm disruptions, correlates with the dose of cosmic radiation. Therefore, according to IARC, the estimates of cancer risk in cumulative radiation dose categories could also be interpreted to roughly reflect the frequency of circadian rhythm disruptions. This assumption, however, disregards that daytime flights in the north-south direction, thus along one meridian, would contribute to the radiation dose but per definition not lead to "circadian disruption".

The prostate cancer incidence in aircraft crews has been found elevated for pilots, but not for cabin crew, in several of the older studies. This excess risk has decreased over time and is, according to IARC, probably attributable to the use of prostate specific antigen (PSA) testing, which was common in pilots much earlier than in the general population. The two largest and most recent studies available in this category have found no elevated risks for prostate cancer mortality $(20,21)$. Only two reports on prostate cancer risks from other shift-working populations have been considered by IARC. In one study, a relative risk (RR) of 2.3 based on three cases was seen in persons working in fixed night shifts, while a RR of 3.0 (confidence interval (CI) 1.2 to 7.7; seven cases) resulted for rotating shift workers (22). The other study found an odds ratio (OR) of 1.19 (CI 1.0 to 1.42) for persons who "normally worked full-time rotating" shift, but it did not explain what "normally" meant (23). Contrary to IARC's reading of the paper there was no apparent trend with cumulative shift exposure. A third study did not enter into this comparison, which reported standardised incidence ratios close to unity for persons who worked in occupations with $>40 \%$ shift workers (6).

The evidence found by IARC for other cancers is even weaker and will not be discussed in detail in this 
article. The picture gained so far, however, provokes the question whether there was indeed enough evidence for the carcinogenicity of shift work at the time of the IARC assessment to warrant a classification of this link as "probable". We may also ask whether this ruling, if warranted, should apply to all cancers or only to female breast cancer.

\section{STUDIES SINCE THE IARC ASSESSMENT}

We carried out a PubMed literature search using the search term "shift work OR night work OR circadian disruption AND cancer" for the period between 2007 and the end of 2011. This search yielded 363 hits, which were then restricted to ten original epidemiologic studies in humans; excluding reviews, studies targeting exposures that may include but go beyond shift work (e.g., light at night), and studies examining surrogates for effects (e.g., cancer biomarkers) (Table 2). One additional study, which was presented at the International $\mathrm{EPICOH}$ and MEDICHEM Meeting in Taiwan but has not been published to date, is further mentioned as personal communication.

Since 2007, six new studies have emerged which can shed more light on the possible link between shift work and female breast cancer. One study in a population-based Chinese cohort found a hazard ratio (HR) of 1.0 (CI 0.9 to 1.2) for ever working night shifts on the basis of a job exposure matrix; the HR was 0.9 (CI 0.7 to 1.1) on the basis of self-reported history of night shift work (24). In 2010, data from a nested case-control study in a different cohort consisting of 267,000 Chinese textile workers were presented for the first time in Taiwan. The RR for

Table 1 Heterogeneity in exposure metrics and thresholds in female breast cancer studies (non-aircraft) quoted in the IARC assessment $;{ }^{*} R R / O R=$ relative risk or odds ratio, as applicable; $C I=$ confidence interval

\begin{tabular}{|c|c|c|c|c|}
\hline Study type & Population & $\begin{array}{l}\text { Risk estimate } \\
\text { (OR/RR; CI)* }\end{array}$ & $\begin{array}{c}\text { Exposure to shift } \\
\text { work }\end{array}$ & $\begin{array}{c}\text { Source } \\
\text { (ref number) }\end{array}$ \\
\hline Cohort & $\begin{array}{l}\text { Nurses, NHS } \\
(n=121,701)\end{array}$ & $1.36(1.0$ to 1.78$)$ & $\geq 30$ years & $\begin{array}{l}\text { Schernhammer et al. } \\
2001 \text { (4) }\end{array}$ \\
\hline Cohort & $\begin{array}{l}\text { Nurses, NHS II } \\
(\mathrm{n}=116,087)\end{array}$ & $1.79(1.06$ to 3.01$)$ & $\geq 20$ years & $\begin{array}{c}\text { Schernhammer et al. } \\
2006(5)\end{array}$ \\
\hline Cohort & $\begin{array}{l}\text { General population } \\
\quad(n=1,148,661)\end{array}$ & $0.97(0.67$ to 1.40$)$ & $\begin{array}{c}\text { occupation with } \\
>40 \% \text { shift workers }\end{array}$ & $\begin{array}{c}\text { Schwartzbaum et al. } \\
2007 \text { (6) }\end{array}$ \\
\hline $\begin{array}{l}\text { Nested case- } \\
\text { control }\end{array}$ & $\begin{array}{l}\text { Radio and telegraph } \\
\text { operators, } \\
50 \text { cases, } \\
\text { 4-7 matched controls }\end{array}$ & $0.9(0.3$ to 2.9$)$ & $\begin{array}{c}\text { age }<50 \text { and shift work } \\
>3.1 \text { years } \\
\text { age } \geq 50 \text { and shift work } \\
>3.1 \text { years }\end{array}$ & Tynes et al. 1996 (7) \\
\hline Case-control & $\begin{array}{l}\text { General population, } \\
7035 \text { cases, one } \\
\text { matched control per } \\
\text { case }\end{array}$ & $1.5(1.2$ to 1.7$)$ & $\begin{array}{c}\geq 0.5 \text { year in } \\
\geq 1 \text { trade in } \\
\text { which } \geq 60 \% \\
\text { of the female } \\
\text { responders had night } \\
\text { time } \\
\text { schedules }\end{array}$ & Hansen 2001 (8) \\
\hline $\begin{array}{l}\text { Nested case- } \\
\text { control }\end{array}$ & $\begin{array}{c}\text { Nurses, } \\
537 \text { cases, } \\
4 \text { matched controls per } \\
\text { case }\end{array}$ & $1.3(0.8$ to 2.0$)$ & $\begin{array}{l}15 \text { to } 29 \text { years } \\
\geq 30 \text { years }\end{array}$ & Lie et al. 2006 (9) \\
\hline Case-control & $\begin{array}{l}\text { General population, } \\
813 \text { cases, } 792 \text { age } \\
\text { matched controls }\end{array}$ & $1.4(1.0$ to 2.0$)$ & $\begin{array}{l}\text { ever night shift (at } \\
\text { least } 3 \text { nights per } \\
\text { week) }\end{array}$ & Davis et al. 2001 (10) \\
\hline Case-control & $\begin{array}{c}\text { General population, } \\
576 \text { cases, } 585 \text { age } \\
\text { matched controls }\end{array}$ & $\begin{array}{l}0.55(0.3 \text { to } 0.9) \\
1.2(0.9 \text { to } 1.6)\end{array}$ & $\begin{array}{l}\text { any overnight shift } \\
\text { evening shift only }\end{array}$ & O'Leary et al. 2006 (11) \\
\hline
\end{tabular}


Table 2 Studies on shift work and cancer, published after the IARC assessment; *RR/OR/HR = relative risk, odds ratio or hazard ratio, as applicable; $C I=$ confidence interval

\begin{tabular}{|c|c|c|c|c|}
\hline $\begin{array}{l}\text { Study type and } \\
\text { cancer of } \\
\text { interest }\end{array}$ & Population & $\begin{array}{c}\text { Risk estimate } \\
(\mathrm{OR} / \mathrm{RR} / \mathrm{HR} ; \mathrm{CI})^{*}\end{array}$ & Exposure metric & $\begin{array}{c}\text { Source } \\
\text { (ref number) }\end{array}$ \\
\hline $\begin{array}{l}\text { Cohort } \\
\text { Female breast }\end{array}$ & $\begin{array}{l}\text { General population, } \\
\text { Shanghai Women's } \\
\text { Health Study, } \\
(n=73,049)\end{array}$ & $1.0(0.9$ to 1.2$)$ & $\begin{array}{l}\text { ever night shift (job exposure } \\
\text { matrix) } \\
\text { ever night shift (self-report) }\end{array}$ & $\begin{array}{l}\text { Pronk et al. } 2010 \\
\text { (24) }\end{array}$ \\
\hline $\begin{array}{l}\text { Case-control } \\
\text { Female breast }\end{array}$ & $\begin{array}{l}\text { General population, } \\
857 \text { cases, } \\
892 \text { controls }\end{array}$ & $\begin{array}{l}0.98(0.74 \text { to } 1.29) \\
1.01(0.68 \text { to } 1.50) \\
0.91(0.38 \text { to } 2.18) \\
2.49(0.87 \text { to } 7.18)\end{array}$ & $\begin{array}{l}\text { ever shift work } \\
\text { ever night work } \\
10 \text { to } 19 \text { years night } \\
\geq 20 \text { years night }\end{array}$ & $\begin{array}{l}\text { Pesch et al. } 2010 \\
\text { (25) }\end{array}$ \\
\hline $\begin{array}{l}\text { Case-control } \\
\text { Female breast }\end{array}$ & $\begin{array}{l}\text { General population, } \\
1230 \text { cases, } \\
1315 \text { controls }\end{array}$ & $\begin{array}{l}1.4(0.9 \text { to } 2.1) \\
2.4(0.9 \text { to } 6.0) \\
1.5(0.9 \text { to } 2.6)\end{array}$ & $\begin{array}{c}\text { employed }>10 \text { years as nurse } \\
\text { textile workers } \\
\text { tailors/dressmakers }\end{array}$ & $\begin{array}{l}\text { Villeneuve et al. } \\
2011(26)\end{array}$ \\
\hline $\begin{array}{l}\text { Nested case- } \\
\text { control } \\
\text { Female breast }\end{array}$ & $\begin{array}{c}\text { Danish nurses, } \\
310 \text { cases, } 4 \text { age } \\
\text { matched controls per } \\
\text { case }\end{array}$ & $\begin{array}{l}0.9(0.4 \text { to } 1.9) \\
1.8(1.2 \text { to } 2.8) \\
2.9(1.1 \text { to } 8.0)\end{array}$ & $\begin{array}{l}\text { ever evening shift, never } \\
\text { night } \\
\text { ever after midnight rotating } \\
\text { shift, never permanent night } \\
\text { ever permanent night in } \\
\text { addition to rotating night } \\
\text { shifts }\end{array}$ & $\begin{array}{c}\text { Hansen and Stevens } \\
2011(27)\end{array}$ \\
\hline $\begin{array}{l}\text { Nested case- } \\
\text { control } \\
\text { Female breast }\end{array}$ & $\begin{array}{l}\text { Norwegian nurses, } \\
699 \text { cases, } \\
895 \text { frequency } \\
\text { matched controls }\end{array}$ & $\begin{array}{l}1.1(0.8 \text { to } 1.6) \\
1.2(0.8 \text { to } 1.7) \\
1.8(1.1 \text { to } 2.8)\end{array}$ & $\begin{array}{c}\text { worked } \geq 5 \text { years with } \\
\geq 3 \text { consecutive night shifts } \\
\text { worked }<5 \text { years with } \\
\geq 6 \text { consecutive night shifts } \\
\text { worked } \geq 5 \text { years with } \\
\geq 6 \text { consecutive night shifts }\end{array}$ & Lie et al. 2011 (28) \\
\hline $\begin{array}{l}\text { Cohort } \\
\text { Prostate }\end{array}$ & $\begin{array}{l}4995 \text { male industry } \\
\text { workers, age } 49 \text { to } \\
65 \text { years ( } 4168 \\
\text { daytime workers, } \\
827 \text { shift workers, } 4 \\
\text { exposed cases) }\end{array}$ & $1.79(0.57$ to 5.68$)$ & $\begin{array}{l}\text { three-shift work for }>80 \% \\
\text { of career }\end{array}$ & $\begin{array}{l}\text { Kubo et al. } 2011 \\
\text { (29) }\end{array}$ \\
\hline Cohort Prostate & $\begin{array}{c}\text { General population } \\
\text { (15 million, 339,973 } \\
\text { cases) }\end{array}$ & $\begin{array}{c}\text { All risks for } \\
\text { occupations with } \\
\text { shift work around } \\
\text { unity }\end{array}$ & $\begin{array}{l}\text { Occupation with high } \\
\text { probability for night work }\end{array}$ & $\begin{array}{l}\text { Pukkala et al. } 2009 \\
\text { (30) }\end{array}$ \\
\hline $\begin{array}{l}\text { Cohort } \\
\text { Ovarian }\end{array}$ & $\begin{array}{l}\text { Nurses, NHS I+II } \\
(\mathrm{n}=181,548), 718 \\
\text { cases }\end{array}$ & $\begin{array}{l}1.28(0.84 \text { to } 1.94) \\
0.80(0.51 \text { to } 1.23)\end{array}$ & $\begin{array}{l}15 \text { to } 19 \text { years rotating night } \\
\text { shift } \\
\geq 20 \text { years rotating night shift }\end{array}$ & $\begin{array}{l}\text { Poole et al. } 2011 \\
\text { (31) }\end{array}$ \\
\hline $\begin{array}{l}\text { Cohort } \\
\text { Skin melanoma }\end{array}$ & $\begin{array}{c}\text { Nurses, NHS I } \\
(\mathrm{n}=68,336), 10,799 \\
\text { cases }\end{array}$ & $\begin{array}{l}0.80(0.51 \text { to } 1.23) \\
\quad \text { skin cancer } \\
0.56(0.36 \text { to } 0.87) \\
\text { melanoma }\end{array}$ & $>10$ years rotating shift & $\begin{array}{l}\text { Schernhammer et al. } \\
2011(32)\end{array}$ \\
\hline $\begin{array}{l}\text { Cohort } \\
\text { Non-Hodgkin's } \\
\text { lymphoma }\end{array}$ & $\begin{array}{c}\text { General population } \\
(\mathrm{n}=1,669,272), 6,307 \\
\text { NHL cases }\end{array}$ & $1.10(1.03$ to 1.19$)$ & $\begin{array}{l}\text { Occupation with high } \\
\text { probability for night work }\end{array}$ & $\begin{array}{l}\text { Lahti et al. } 2008 \\
\text { (33) }\end{array}$ \\
\hline
\end{tabular}


having worked shifts for 1 to $<10$ years, 10 to $<20$ years, and $20+$ years compared with less than 1 year were $0.99,1.0$, and 0.92 , respectively (W. Li, personal communication). In a re-analysis of case-control data originally gathered for a different set of risk factors, shift work (ever vs. never) had an OR for female breast cancer of 0.98 (CI 0.74 to 1.29); night work (ever vs. never) was associated with an OR of 1.01 (CI 0.68 to $1.50)$; there were non-significantly reduced risk estimates for exposure metrics below the median, and non-significantly increased risks above the median. The OR was 2.49 (CI 0.87 to 7.18 ) for more than 20 years of night shift work, while all other risk estimates were below unity (25). Surprisingly, the authors of this study concluded that their findings were "in line with the IARC classification.” In a French case-control study on occupation as a risk factor for breast cancer, an OR of 1.4 (CI 0.9 to 2.1) emerged for women employed for more than 10 years as nurses. An overall OR of 2.4 (CI 0.9 to 6.0 ) was reported in textile workers and 1.5 (CI 0.9 to 2.6) in tailors/dressmakers, with no information available on working time schedules of these occupational groups (26). In a nested case-control study from a cohort of Danish nurses, significantly increased ORs ranging between 1.8 and 2.9 were found when work after midnight was compared with permanent day work (27). There was no apparent effect of evening work, if night work was excluded. An interesting new aspect was added by the re-analysis of data from a Norwegian case-control study $(9,28)$. Here, a significantly increased OR of 1.8 (CI 1.1 to 2.8 ) was seen in nurses who worked $\geq 5$ years with $\geq 6$ consecutive night shifts.

Two new studies have emerged regarding prostate cancer. An OR of 1.79 (CI 0.57 to 5.68), based on only four exposed cases, was seen in persons who had performed three-shift work for $>80 \%$ of their career, if compared to persons who had never worked shifts (29). On the other hand, no indication of an association with occupation was seen among 339,973 prostate cancer cases in a cohort of 15 million people aged 30 to 64 years in the 1960,1970,1980/1981 and/or 1990 censuses in Denmark, Finland, Iceland, Norway and Sweden (30).

Little new information has emerged for other cancer types. In one study, the HR for ovarian cancer was 1.28 (CI 0.84 to 1.94 ) in women who performed 15 to 19 years of rotating night shifts, and 0.80 (CI 0.51 to 1.23 ) for those with more than 20 years of shift work (31). A $14 \%$ decreased risk of skin cancer, and $44 \%$ decreased risk of melanoma, was seen after more than 10 years of rotating night shifts (32). The RR for non-Hodgkin's lymphoma was 1.10 (CI 1.03 to 1.19 ) for men who worked night shifts, and it increased to 1.28 (CI 1.03 to 1.59 ) when a lag period of 10 years was applied (33).

\section{CONSEQUENCES FOR SHIFT WORKERS IN INDUSTRY - EXPERIENCE FROM A LARGE CHEMICAL COMPANY}

While we agree with the conclusion drawn by Wang et al. (34) in their in-depth review that "heterogeneity of study exposures and outcomes and emphasis on positive but non-significant results make it difficult to draw general conclusions" from the existing literature on shift work and cancer, this lack of evidence should not lead to complacency in the persons who are responsible for workers' health. Recommendations for measures to counteract expected negative effects of night work are more often "eminence-based" than "evidence-based" (35). These recommendations include a selection of "shift tolerant" individuals, favouring of forward rotating shift schedules (morning - afternoon - night) over backward rotation (night - afternoon - day), avoidance of multiple night-shifts in a row, interventions through bright light or medication, physical exercise, and others.

Given that shift work is simply unavoidable in many occupations and industries, it is the duty of occupational physicians and scientists to examine the potential risks associated with this kind of work organisation. Health risks, if any, have to be minimised as far as possible and, where they can not be avoided, means of intervention and - if necessary - compensation have to be discussed. To this end we performed studies in more than 17.000 shift and 13.000 day workers at a major chemical site in Germany. We compared the acute and chronic illness experience, the accident rates, and the overall mortality across these groups of workers with the surprising result of generally more favourable outcomes for shift workers, after adjusting for smoking habits and other known relevant confounders $(36,37)$. Even the overall cancer incidence was reduced in shifts if compared to day workers. It has to be emphasised, however, that owing to German data protection legislation our database is weak regarding cancer incidence, and our conclusions regarding the question of carcinogenicity of shift work in our workforce are preliminary. There are several 
possible explanations for the unexpected lack of adverse health effects of shift work in this study population. First, the shift system in place never requires more than one night shift in a row. Second, it is forward rotating, with night work always followed by a resting period of 24 (old system) or 48 hours (new system). With regard to the IARC concept of "circadian disruption", we hypothesise that desynchronisation of circadian biological rhythms does not occur to a sizable degree under these circumstances. This assumption can further be supported by the observation that workers in both shift systems did not complain about subjective health impairment more than day workers with the same socio-economic background (38). Whether health promotion programs for workers result in long-term health benefits is equivocal (39, 40 ), but it may reasonably be assumed provided such programs are not only offered on a one-time basis. We were indeed able to demonstrate that shift workers in our studied populations were more often participating in such programs than day workers, and participation in health promotion activities was associated with reduced overall mortality, if compared to nonparticipation (41). However this reduced mortality was not apparently triggered by reduced cancer incidence in participants (RR 1.07; CI 0.84 to 1.36).

\section{CONCLUSION}

Based on the literature available, it can not be confidently ruled out that shift work including night work may, possibly depending on the way how it is organised, increase the risk for some cancers in those who perform it. However, at this point in time there is no reason to believe that shift-workers in general face an increased cancer risk. In any case, shift schedules can probably be organised in ways that minimise the associated health risks, and the risks may be further reduced through the implementation of structured and sustained health promotion programs specifically tailored to the needs of shift workers. The recommendation to use fast forward rotating shift schedules with no more than one or two subsequent night shifts can be supported on the basis of our experience.

\section{REFERENCES}

1. Straif K, Baan R, Grosse Y, Secretan B, El Ghissassi F, Bouvard V, Altieri A, Benbrahim-Tallaa L, Cogliano V.
Carcinogenicity of shift-work, painting, and fire-fighting. Lancet Oncol 2007;8:1065-6.

2. Kolstad HA. Nightshift work and risk of breast cancer and other cancers - a critical review of the epidemiologic evidence. Scand J Work Environ Health 2008;34:5-22.

3. World Health Organization, International Agency for Research on Cancer. Painting, Firefighting, and Shiftwork. IARC Monographs on the Evaluation of Carcinogenic Risks to Humans Vol. 98, 2010 [displayed 30 April 2012]. Available at http://monographs.iarc.fr/ENG/Monographs/vol98/ mono98.pdf

4. Schernhammer ES, Laden F, Speizer FE, Willett WC, Hunter DJ, Kawachi I, Colditz GA. Rotating night shifts and risk of breast cancer in women participating in the nurses" health study. J Natl Cancer Inst 2001;93:1563-8.

5. Schernhammer ES, Kroenke CH, Laden F, Hankinson SE. Night work and risk of breast cancer. Epidemiology 2006;17:108-11.

6. Schwartzbaum J, Ahlbom A, Feychting M. Cohort study of cancer risk among male and female shift workers. Scand J Work Environ Health 2007;33:336-43.

7. Tynes T, Hannevik M, Andersen A, Vistnes AI, Haldorsen T. Incidence of breast cancer in Norwegian female radio and telegraph operators. Cancer Causes Control 1996;7:197204.

8. Hansen J. Increased breast cancer risk among women who work predominantly at night. Epidemiology 2001;12:74-7.

9. Lie JA, Roessink J, Kjaerheim K. Breast cancer and night work among Norwegian nurses. Cancer Caus Control 2006;17:39-44.

10. Davis S, Mirick DK, Stevens RG. Night shift work, light at night, and risk of breast cancer. J Natl Cancer Inst 2001;93:1557-62.

11. O'Leary ES, Schoenfeld ER, Stevens RG, Kabat GC, Henderson K, Grimson R, Gammon MD, Leske MC; Electromagnetic Fields and Breast Cancer on Long Island Study Group. Shift work, light at night, and breast cancer on Long Island, New York. Am J Epidemiol 2006;164:35866.

12. Pukkala E, Auvinen A, Wahlberg G. Incidence of cancer among Finnish airline cabin attendants, 1967-92. BMJ 1995;311:649-52.

13. Lynge E. Risk of breast cancer is also increased among Danish female airline cabin attendants. BMJ. 1996;312:253.

14. Wartenberg D, Stapleton CP. Risk of breast cancer is also increased among retired US female airline cabin attendants. BMJ 1998;316:1902.

15. Haldorsen T, Reitan JB, Tveten U. Cancer incidence among Norwegian airline cabin attendants. Int J Epidemiol 2001;30:825-30.

16. Rafnsson V, Tulinius H, Jónasson JG, Hrafnkelsson J. Risk of breast cancer in female flight attendants: a populationbased study (Iceland). Cancer Causes Control 2001;12:95101.

17. Blettner M, Zeeb H, Langner I, Hammer GP, Schafft T. Mortality from cancer and other causes among airline cabin attendants in Germany, 1960-1997. Am J Epidemiol 2002;156:556-65

18. Reynolds P, Cone J, Layefsky M, Goldberg DE, Hurley S. Cancer incidence in California flight attendants (United States). Cancer Causes Control 2002:13:317-24. 
19. Linnersjö A, Hammar N, Dammström BG, Johansson M, Eliasch H. Cancer incidence in airline cabin crew: experience from Sweden. Occup Environ Med 2003;60:810-14.

20. Zeeb H, Blettner M, Langner I, Hammer GP, Ballard TJ, Santaquilani M, Gundestrup M, Storm H, Haldorsen T, Tveten U, Hammar N, Linnersjö A, Velonakis E, Tzonou A, Auvinen A, Pukkala E, Rafnsson V, Hrafnkelsson J. Mortality from cancer and other causes among airline cabin attendants in Europe: a collaborative cohort study in eight countries. Am J Epidemiol 2003;158:35-46.

21. Blettner M, Zeeb H, Auvinen A, Ballard TJ, Caldora M, Eliasch H, Gundestrup M, Haldorsen T, Hammar N, Hammer GP, Irvine D, Langner I, Paridou A, Pukkala E, Rafnsson V, Storm H, Tulinius H, Tveten U, Tzonou A. Mortality from cancer and other causes among male airline cockpit crew in Europe. Int J Cancer 2003:106:946-52.

22. Kubo T, Ozasa K, Mikami K, Wakai K, Fujino Y, Watanabe Y, Miki T, Nakao M, Hayashi K, Suzuki K, Mori M, Washio M, Sakauchi F, Ito Y, Yoshimura T, Tamakosh A. Prospective cohort study of the risk of prostate cancer among rotatingshift workers: findings from the Japan collaborative cohort study. Am J Epidemiol 2006;164:549-55.

23. Conlon M, Lightfoot N, Kreiger N. Rotating shift work and risk of prostate cancer. Epidemiology 2007;18:182-3.

24. Pronk A, Ji B-T, Shu X-O, Xue S, Yang G, Li H-L, Rothman N, Gao Y-T, Zheng W, Chow W-H. Night-shift work and breast cancer risk in a cohort of Chinese women. Am J Epidemiol 2010;171:953-9.

25. Pesch B, Harth V, Rabstein S, Baisch C, Schiffermann M, Pallapies D, Bonberg N, Heinze E, Spickenheuer A, Justenhoven C, Brauch H, Hamann U, Ko Y, Straif K, Brüning T. Night work and breast cancer - results from the German GENICA study. Scand J Work Environ Health 2010;36:134-41

26. Villeneuve S, Févotte J, Anger A, Truong T, Lamkarkach F, Gaye O, Kerbrat P, Arveux P, Miglianico L, Imbernon E, Guénel P. Breast cancer risk by occupation and industry: analysis of the CECILE study, a population-based casecontrol study in France. Am J Ind Med 2011;54:499-509.

27. Hansen J, Stevens RG. Case-control study of shift-work and breast cancer risk in Danish nurses: impact of shift systems. Eur J Cancer 2011 (Epub ahead of print)

28. Lie JA, Kjuus H, Zienolddiny S, Haugen A, Stevens RG, Kjaerheim K. Night work and breast cancer risk among Norwegian nurses: assessment by different exposure metrics. Am J Epidemiol 2011;173:1272-9.

29. Kubo T, Oyama I, Nakamura T, Kunimoto M, Kadowaki K, Otomo H, Fujino Y, Fujimoto N, Matsumoto T, Matsuda S. Industry-based retrospective cohort study of the risk of prostate cancer among rotating-shift workers. Int J Urol 2011;18:206-11.

30. Pukkala E, Martinsen JI, Lynge E, Gunnarsdottir HK, Sparén P, Tryggvadottir L, Weiderpass E, Kjaerheim K. Occupation and cancer - follow-up of 15 million people in five Nordic countries. Acta Oncol 2009;48:646-790.

31. Poole EM, Schernhammer ES, Tworoger SS. Rotating night shift work and risk of ovarian cancer. Cancer Epidemiol Biomarkers Prev 2011;20:934-8.

32. Schernhammer ES, Razavi P, Li TY, Qureshi AA, Han J. Rotating night shifts and risk of skin cancer in the nurses' health study. J Natl Cancer Inst 2011;103:602-6.

33. Lahti TA, Partonen T, Kyyrönen P, Kauppinen T, Pukkala E. Night-time work predisposes to non-Hodgkin lymphoma. Int J Cancer 2008;123:2148-51.

34. Wang X-S, Armstrong MEG, Cairns BJ, Key TJ, Travis RC. Shift work and chronic disease: the epidemiological evidence. Occup Med 2011;61:78-9.

35. Pallesen S, Bjorvatn B, Mageroy N, Saksvik IB, Waage S, Moen BE. Measures to counteract the negative effects of night work. Scand J Work Environ Health 2010;36:109120

36. Ott MG, Oberlinner C, Lang S, Hoffmann G, Nasterlack M, Pluto R-P, Trauth B, Messerer P, Zober A. Health and safety protection for chemical industry employees in a rotating shift system: program design and acute injury and illness experience at work. J Occup Environ Med 2009;51:22131.

37. Oberlinner C, Ott MG, Nasterlack M, Yong M, Messerer P, Zober A, Lang S. Medical program for shift workers - impacts on chronic disease and mortality outcomes. Scand J Work Environ Health 2009;35:309-18.

38. Yong M, Nasterlack M, Pluto R-P, Elmerich K, Karl D, Knauth $P$. Is health, measured by work ability index, affected by 12 -hour rotating shift schedules? Chronobiol Int 2010;27:1135-48.

39. Merrill RM, Aldana SG, Garrett J, Ross C. Effectiveness of a workplace wellness program for maintaining health and promoting healthy behaviors. J Occup Environ Med 2011;53:782-7.

40. Saltychev M, Laimi K, El-Metwally A, Oksanen T, Pentti J, Virtanen M, Kivimäki M, Vahtera J. Effectiveness of multidisciplinary primary prevention in decreasing the risk of work disability in a low-risk population. Scand J Work Environ Health 2012;38:27-37.

41. Ott MG, Yong M, Zober A, Nasterlack M, Messerer P, Pluto R-P, Lang S, Oberlinner C. Impact of an occupational health promotion program on subsequent illness and mortality experience. Int Arch Occup Environ Health 2010;83:88794. 


\section{Sažetak}

\section{RAD U SMJENAMA I RAK - ZNANSTVENE SPOZNAJE I PRAKTIČNE POSLJEDICE}

Stručna radna skupina, koju je okupio Program monografija Međunarodne agencije za istraživanje raka (eng. International Agency for Research on Cancer, krat. IARC), 2007. godine zaključila je da je rad u smjenama, koji uključuje prekid cirkadijurnoga ritma, najvjerojatnije kancerogen za ljude (skupina 2A). Procijenili smo epidemiološku osnovu takvoga zaključka i usredotočili se na rak dojke i rak prostate između ostalih malignih bolesti. Nadalje, razmatrali smo praktične posljedice koje rad u smjenama ima na radnike u kemijskoj kompaniji BASF u okvirima novih spoznaja na tom području.

Istražili smo literaturu, uključujući i epidemiološka istraživanja studije koje citira IARC kao i noviju literaturu o povezanosti rada u smjenama i raku.

Od zaključka IARC-a nastalo je jedanaest novih istraživanja, a deset ih je već objavljeno. Njihovi rezultati ipak ne dovode do konačnoga i jednoznačnoga zaključka. Heterogenost mjerenja izloženosti i ishoda istraživanja i naglasak na pozitivne, ali ne uvijek i značajne rezultate, otežavaju postavljanje općih zaključaka. Jednako tako u nekoliko nedavno objavljenih recenzija i komentara ne iznose se jednoznačni rezultati. Objavljeni znanstveno utemeljeni dokazi samo upućuju, ali ne dovode u očiglednu vezu noćni rad i rak dojke. Nadalje, ograničeni su i nedosljedni za malignome na drugim lokacijama u tijelu, kao i za sve malignome zajedno.

U ovom trenutku nije moguće odbaciti hipotezu da smjenski rad (uključujući noćni rad) može povećati rizik nastanka određenih malignih bolesti. Međutim, raspored smjena se može organizirati na način da se opasnosti za zdravlje svedu na najmanju moguću mjeru. Rizici se također mogu dodatno smanjiti provedbom strukturiranih programa promicanja održivoga zdravlja koji bi bili posebno osmišljeni prema potrebama radnika.

KLJUČNE RIJEČI: noćni rad, prekid cirkadijurnog ritma, rak dojke, rak prostate

\section{CORRESPONDING AUTHOR:}

Dr. Michael Nasterlack

Occupational Medicine \& Health Protection

BASF SE, 67056 Ludwigshafen, Germany

E-mail:michael.nasterlack@basf.com 